\title{
Chemical and microbial qualities of morning and evening milk collected from selected dairy farms in Chittagong City of Bangladesh
}

\author{
S Akter ${ }^{1}$, MAA Galib², H kabir ${ }^{1}$, SK Nath ${ }^{3}$, K Afrin $^{3}$, MS Sarker ${ }^{4} *$ \\ ${ }^{1}$ Department of Medicine and Surgery, Chittagong Veterinary and Animal Sciences University, Chittagong; \\ ${ }^{3}$ Department of Animal Science and Nutrition; ${ }^{4}$ Department of Microbiology and Veterinary Public Health, \\ Chittagong Veterinary and Animal Sciences University, Khulshi 4225, Chittagong, ${ }^{2}$ Department of Physiology \\ and Pharmacology, Hajee Mohammad Danesh Science and Technology University, Dinajpur, Bangladesh
}

\begin{abstract}
This study was undertaken to evaluate the nutritional and microbiological qualities of raw milk in the Chittagong City. Eighty samples of raw milk of cow were collected in the morning and evening from the surrounding farms of Chittagong Veterinary and Animal Sciences University (CVASU), Chittagong, Bangladesh. The results of compositional analysis evolved that fat, SNF, protein, lactose, specific gravity, freezing point and mineral were $(3.94 \pm 0.22 \%),(7.91 \pm 0.17 \%),(3.11 \pm 0.08 \%),(4.32 \pm 0.10 \%)$, $(1.026 \pm 0.00),(-0.46 \pm 0.007),(0.68 \pm 0.01 \%)$, respectively. The fat $\%$ of evening milk was significantly higher $(p<0.001)$ than morning milk. Rest of the parameters were not significant. Microbiological enumeration revealed for the counts of total viable bacteria (cfu/ml) and coliform (cfu/ml) were $730500 \pm 639$ and $280 \pm 1.36$ in the morning milk and $628625 \pm 566$ and $326 \pm 1.84$ in the evening milk, respectively. The results of the current study indicated that the nutritional quality of evening raw milk was higher than in the morning raw milk.
\end{abstract}

Key words: Morning milk, evening milk, quality, Chittagong City

Bangladesh Animal Husbandry Association. All rights reserved. Bang. J. Anim. Sci. 2015. 44(3): 171-175

\section{Introduction}

Milk has been considered as ideal food for human since long before the recorded history. Milk is renowned as an 'almost complete' as well as natural nutritious food for all mammals including human being (Debnath et al. 2014). According to Byron et al. (1974), the constituents of milk are water $(87.20 \%)$, Protein $(3.50 \%)$, Fat $(3.70 \%)$, milk sugar or lactose $(4.90 \%)$, ash $(0.70 \%)$ and Dry matter $(12.80 \%)$. These components may fluctuate by type of breed, type of feed they consumed, stage of lactation, age of cow, season etc and between the individuals of same breed (Ghosh et al. 1965). Milk is the most desirable food of high biological value and it presents almost all ingredients of food in exact proportion and in any digestible form. It is imperative to study milk fat-protein ratio (F/P) in order to assess nutrition, nutrients conversion and metabolism. The optimum F/P ratio is $1.2-1.4$ (Vladimír et al. 2005). Richardt (2004), confirms that the F/P ratio higher than 1.5 dictates subclinical ketosis whereas the ratio lower than 1.1 that suspected rumen acidosis.
Chemical and microbiological analysis is an important tool to monitor the quality of dairy products. Milk adulteration can causes the spoilage of dairy products and to ensure the quality of milk requires essential and higher importance on regulatory aspects. Advanced methods have to take for the analysis, monitoring, production and processing of milk. Fresh milk considered as a complete diet because it contains the essential nutrients as lactose, fat, protein, mineral and vitamins in balanced ratio as compared to the other foods (Shojaei and Yadollahi, 2008). Cousin (1982) stated that there were a lot of sources for bacterial contamination of milk like udder, skin surface, litter, floor, flies, insects and rodents, water supply, milker's hand, utensils, atmosphere etc. Oliver et al. (2005) revealed that milk and milk products from raw milk can port a range of microorganisms and can be vital sources of food borne diseases.

Public health authority is employed the standards of milk and dairy products based on Bangladesh Standards (BDS). So it is important to evaluate nutritional and microbiological quality of raw cow

*Corresponding author: samun_cvasu@yahoo.com 


\section{Chemical and microbial qualities of milk}

milk. Therefore, the present study was carried out in order to evaluate the nutritional and microbial qualities of morning and evening milk of cow collected from the surrounding farms of CVASU.

\section{Materials and Methods}

\section{Place and Duration}

The study was carried out in Dairy science Laboratory belongs to the Department of Dairy and poultry Science at Chittagong Veterinary and Animal Sciences University (CVASU), during a period from 5th September to 10th October 2013.

\section{Collection of milk sample}

A total number of 80 samples of raw milk were collected in the morning (40 samples) and in the evening (40 samples). All the samples were collected from surrounding farms of CVASU campus (Jalalabad, Foy's lake area). The nutritional and microbiological qualities of each sample were analyzed. Raw milk samples were collected from the bulk sources of fluid raw milk through proper mixing with the help of plunger and dipper at morning and evening from each farm. Soon after collection the samples were kept into the ice box for ceasing the growth and activity of acid producing organisms and transported to the laboratory.

\section{Methods for testing raw milk}

The collected milk samples were kept in the refrigerator at $40^{\circ} \mathrm{C}$ until the tests were conducted. Before analysis each sample was pre warmed for few minutes at $600^{\circ} \mathrm{C}$. Physiochemical properties (specific gravity, fat percentage, SNF percentage, protein percentage, lactose percentage, Freezing point and Mineral percentage) were determined by Lactoster machine (Germany).

\section{Total Viable Count (TVC)}

TVC were done as per recommendation of APHA (1967). In brief, Bacto agar was used for enumeration of SPC. Each raw milk sample was prepared by ten fold dilution using peptone buffered water. To determine the SPC, using sterile pipette to transfer and to spread of $0.1 \mathrm{ml}$ of each dilution on agar surface. Inoculated plates were incubated at $37^{\circ} \mathrm{C}$ for 48 hours to facilitate viable bacterial growth. After incubation, the colonies were counted. The number of colonies from an individual dilution was multiplied by the dilution factor to obtain the TVC and total count was expressed as colony forming units per milliliter ( cfu /ml).

\section{Coliform count}

The medium used for coliform was Violet Red Bile agar (VRB). Inoculated plates were incubated at $37^{\circ} \mathrm{C}$ for 24 hours. Then, typical pinkish and red colonies were counted and total coliform was calculated.

\section{Data recording and analysis}

SPSS (Version-16) statistical software was used for the calculation of mean, standard error, correlation coefficient ${ }^{\circledR}$, t-test and significant value $(p)$.

\section{Results}

The average nutritional composition of raw milk is shown in Table 1 . The fat, SNF, protein, lactose, specific gravity, freezing point and mineral content of raw milk from different farms were $3.94 \pm 0.22 \%, \quad 7.91 \pm 0.17 \%, \quad 3.11 \pm 0.08 \%$, $4.32 \pm 0.10 \%, \quad 1.026 \pm 0.00,-0.46 \pm 0.007$ and $0.68 \pm 0.01 \%$, respectively.

Table 1. Average nutritional composition of different farm raw milk (Mean \pm SE)

\begin{tabular}{ll}
\hline Parameters & Mean \pm SE \\
\hline Fat & $3.94 \pm 0.22$ \\
SNF & $7.91 \pm 0.17$ \\
Protein & $3.11 \pm 0.08$ \\
Lactose & $4.32 \pm 0.10$ \\
Sp. Gravity & $1.026 \pm 0.0008$ \\
Freezing point & $-0.46 \pm 0.007$ \\
Mineral & $0.68 \pm 0.01$ \\
\hline
\end{tabular}

$\mathrm{N}=80$ (40 at morning +40 at evening)

The morning milk composition of fat, SNF, protein, lactose, specific gravity, freezing point and mineral were $3.12 \pm 0.05 \%, 7.63 \pm 0.27 \%$, $2.97 \pm 0.11 \%, \quad 4.13 \pm 0.15 \%, \quad 1.026 \pm 0.001$, $0.45 \pm 0.0090 .69 \pm 0.01 \%$, respectively (Table 2 ). On the other hand, the evening milk composition of fat, SNF, protein, lactose, specific gravity, freezing point and mineral were $4.75 \pm 0.11 \%$, $8.19 \pm 0.17 \%, \quad 3.25 \pm 0.08 \%, \quad 4.50 \pm 0.10 \%$, $1.027 \pm 0.0009,-0.47 \pm 0.007$ and $0.67 \pm 0.02 \%$, respectively (Table 2 ). In the morning milk, TVC and Coliform count were $730500 \pm 639$ and 
Akter el al. (2015) Bang. J. Amin. Sci. 44(3): 171-175

$280 \pm 1.36$, respectively. But in the evening milk it was $628625 \pm 566$ and $326 \pm 1.84$ (Table 3). Fat protein ration of morning and evening milk were 1.05 and 1.46 , respectively (Table 4 ).

Table 2. Nutritional composition of morning and evening raw milk of different farm

\begin{tabular}{llllllll}
\hline & Fat & SNF & Protein & Lactose & Sp. Gravity & F. point & Mineral \\
\hline $\begin{array}{l}\text { Morning } \\
\text { milking }\end{array}$ & $3.12 \pm 0.05$ & $7.63 \pm 0.27$ & $2.97 \pm 0.11$ & $4.13 \pm 0.15$ & $1.026 \pm 0.001$ & $-0.45 \pm 0.009$ & $0.69 \pm 0.01$ \\
$\begin{array}{l}\text { Evening } \\
\text { milking }\end{array}$ & $4.75 \pm 0.11$ & $8.19 \pm 0.17$ & $3.25 \pm 0.08$ & $4.50 \pm 0.10$ & $1.027 \pm 0.001$ & $-0.47 \pm 0.007$ & $0.67 \pm 0.02$ \\
$\begin{array}{l}\text { Significant } \\
\text { value }\end{array}$ & 0.001 & 0.159 & 0.069 & 0.87 & 0.507 & 0.112 & 0.20 \\
\hline
\end{tabular}

$\mathrm{N}=80$ (40 at morning +40 at evening)

Table 3. Microbial quality of different farm raw milk

\begin{tabular}{ccc}
\hline & TVC $(\mathrm{CFU} / \mathrm{ml})$ & Coliform $(\mathrm{CFU} / \mathrm{ml})$ \\
\hline Morning milking & $730500 \pm 639$ & $280 \pm 1.36$ \\
Evening milking & $628625 \pm 566$ & $326 \pm 1.84$ \\
Significant value & 0.150 & 0.082 \\
\hline
\end{tabular}

$\mathrm{N}=80$ (40 at morning +40 at evening)

Table 4. Fat-protein ratio of milk

\begin{tabular}{cccc}
\hline & Fat & Protein & Fat-protein ratio \\
\hline Morning milk & 3.12 & 2.97 & 1.05 \\
Evening milk & 4.75 & 3.25 & 1.46 \\
Morning and evening milk & 3.94 & 3.11 & 1.26 \\
\hline
\end{tabular}

\section{Discussion}

\section{Physicochemical properties}

The average fat percentage of farm milk was found to be $3.94 \pm 0.22 \%$, which was supported by Debnath et al. (2009) who demonstrated that the butter fat of milk from different sources from Chittagong metropolitan area varied from 3.52 to 4.01. Judkins and Keener (1960) reported that the average fat\% of milk sample was 2.5 to $8.0 \%$. The study indicated that the average SNF content of farm milk was $7.91 \pm 0.17 \%$, which was slightly lower than the findings of Debnath et al. (2009) who reported that SNF\% from farm produced milk, vendor supplied farm milk, vendor supplied rural milk and brand market milk were $8.33,7.98,7.85,8.2 \%$, respectively in Chittagong metropolitan area. The slightly lower SNF value might be due to smaller sample size. In the present study, the average protein and lactose content of farm milk were $3.11 \pm 0.08 \%$ and $4.32 \pm 0.10 \%$, respectively. These values were lower than the values of Eckles et al. (1951), demonstrated that milk should contain
$3.80 \%$ protein and $4.80 \%$ lactose. This variation may be due to the variation of breed. The average specific gravity of farm milk was $1.026 \pm 0.00$, which was supported by Eckles et al. (1951), I slam et al. (1993) and Debnath et al. (2009). The average freezing point and mineral content of farm milk were $-0.46 \pm 0.007$ and $0.68 \pm 0.01 \%$, respectively. According to Eckles et al. (1951), milk should contain $0.65 \%$ minerals and the current study agreed with his finding. The average fat percentage of evening milk was significantly $(P<0.05)$ higher than the morning milk. It was supported by Iqbal et al. (2005). The average SNF, protein, lactose, specific gravity, freezing point and mineral percentage of evening milk was not significantly ( $p>0.05$ ) higher than the morning milk. This study was supported by Iqbal et al. (2005).

\section{Microbial quality}

The average TVC count of morning milk

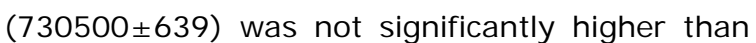
the evening milk $(628625 \pm 566)$ (Table 3$)$. The results of this study correlated with the findings 


\section{Chemical and microbial qualities of milk}

of I knomov et al. (1956) who reported that the total bacterial counts ranged from $1,25,000$ to $9,000,000$ per $\mathrm{ml}$ of milk depending on milking techniques and cleanliness. The number of bacteria in aseptically drawn milk was 10092,000 per $\mathrm{ml}$, but infection occurred subsequently from the skin of animals, milker's hand, cow shed and milking utensils. Lee et al. (1983) conducted an experiment in Seoul of Korea and found that the bacterial count in raw milk ranged from $4 \times 106$ to $2.7 \times 107$ per $\mathrm{ml}$. This result indicated that the average coliform count of morning milk was lower than the evening milk but not statistically significant. The variation in coliform count of the milk may be due to the hygienic maintenance during milking. The results of this investigation were in agreement with the finding of Mutukumira et al. (1996), who found the coliform bacteria was 326 to 240 per ml. Saitanu et al. (1996) experimented and revealed that the total coliform count was of $<1000 \mathrm{CFU} / \mathrm{ml}$.

\section{Fat-protein ratio}

The fat-protein (F/P) ratio of morning and evening milk was 1.26. Richardt (2004) measured the F/P ratio as an important pointer of animal health. Its value above 1.5 in dairy cows indicated a 1.5 times more probability of incidence of mastitis, 7.5 times tendency to lameness and 3.5 times more incidence to ketosis. Vladimir et al. (2005) dictated that the proper F/P ratio for Holstein cows is $1.05-1.18$. High values in the first phase suggested a great energy deficiency. Haas et al. (2004) included that the optimum F/P ratio is 1.2-1.4. Low values are prone to subclinical rumen acidosis which can put in danger the reproductive performance of cows and increase a possible expansion of disorders of mineral metabolism. The F/P ratio higher than 1.4 indicated the sign of energy deficit and if ketone bodies are present, lead to subclinical ketosis. The current study agreed with this range.

\section{Conclusion}

Results of this study showed the chemical and microbial qualities of milk from different local farms. The presence of bacterial population in raw milk indicates defect during collection and processing of milk. The presence of the pathogenic organisms and the high counts of coliforms in milk are indicative of a potentially hazardous product which is likely to be posing a serious health risk to the consumers. Fat protein ratio was in acceptable range. Evening milk was found superior than morning milk due to high chemical composition. The government therefore should conduct frequent inspection of the marketed milks to check whether they meet the minimum legal standards and should monitor the overall hygienic condition surrounding the production and handling of milk. Realistic standards for the raw milks need to be devised and appropriate training should be given to the raw milk producers in hygienic handling of milk.

\section{Acknow ledgements}

Authors are grateful to the academician and stuffs of Department of Dairy and Poultry Science (CVASU) and Owner of the respected farms.

\section{References}

American Public Health Association (APHA) (1967). Standard methods for the examination of dairy products. American Public Health Association. Inc. 12th Edn. New York. P. 90 - 110.

Byron HW, Arnold HJ, Johan AA (1974). Fundamentals of dairy chemistry. 2nd Edn. Westport, Connecticut. The Avi Publishing Company, Inc. P. 2-8.

Cousin MA (1982). Presence and activity of psychrotrophic microorganisms in milk and dairy products. Journal Food Protein. 45: 172-207.

Debnath GK, Kober AKMH, Chanda GC (2009). Quality of Fluid Milk Available in Chittagong Metropolitan Area, proceedings of the sixth annual scientific conference of CVASU, Bangladesh. P.178-182

Debnath GK, Kober AKMH, Chanda T, Chanda GC, Bari MSA (2014). Comparative Study on the Quality of Available Brand and Non Brand Fluid Milk Consumed by the People of Chittagong City of Bangladesh. International Journal of Natural Sciences, 4(1): 16- 20.

Eckles C, Combs C, Macy H (1951). Milk and milk products 4th Edn. Mcgraw-Hill book company, New York, Toronto, London. P. 22-23.

Ghosh SN, Krishnan CPA (1965). Indian Journal of Dairy Science, 17: 190.

Haas D, Hofírek B (2004). The diagnostic importance of milk components for a human 
Akter el al. (2015) Bang. J. Amin. Sci. 44(3): 171-175

and cow's health. (In Czech) CUA Prague, Proceedings of contributions: Milk day. P. 26 $-29$.

I konomov L, Lotov I, Todorov D, Tankov G, Dzhurov TS (1956). Bacteriological studies of Hygiene of milk production of Bulgarian cattle Breeding Farms. Dairy Science Abstract 19: 936.

Iqbal SA, Mido Y (2005). Food Chemistry. Discovery Publishing House, New Delhi, India.

Islam MN, Hussain SMI, Mannan AKMA (1993). Studies on the physical parameters and chemical qualities of market milk in Mymensingh town (Bangladesh). Banglasesh journal of Animal Science. 13: 52.

Judkins HF, Keener HA (1960). Milk production and processing. 4th Edn, New York. P. 227230.

Lee JT, Park SY, Korea IK, Kin HU (1983). Quality of raw milk in Korea. Korean Journal of Dairy Science. 5 (1): 22-28.

Mutukumira AN, Feresu SB, Narbhus JA, Abrahamsen RK (1996). Chemical and Microbiological Quality of raw milk produced by small holder farmers in Zimbabwe. J ournal of Food Protection. 59 (9): 984-987.
Oliver SP, Jayarao BM, Almeida RA (2005). Foodborne pathogens in milk and the dairy farm environment: food safety and public health implications. Foodborne Pathogen and Diseases 2 (2): 115-29.

Richardt W (2004). Milk composition as an indicator of nutrition and health. (In Czech) The Breeding. P. $26-27$.

Saitanu IA, Chuanchuen KR, Nuanuarsuwan S, Koowatananukul C and Rugkhaw V (1996). Microbiological quality of raw cow milk. Thai Journal of Veterinary Medicine 26(3): 193214.

Shojaei ZA, Yadollahi A (2008). Physicochemical and Microbiological Quality of Raw Pasteurized and UHT Milks in Shops. Asian Journal of Scientific Research. 1: 532-538.

Vladimír ČEJNA, Gustav CHLÁDEK (2005). The importance of monitoring changes in milk fat to milk protein ratio in Holstein cows during lactation, Department of Animal Breeding, Mendel University of Agriculture and Forestry in Brno, Zemědělská 1, 61300 Brno, Czech Republic. 